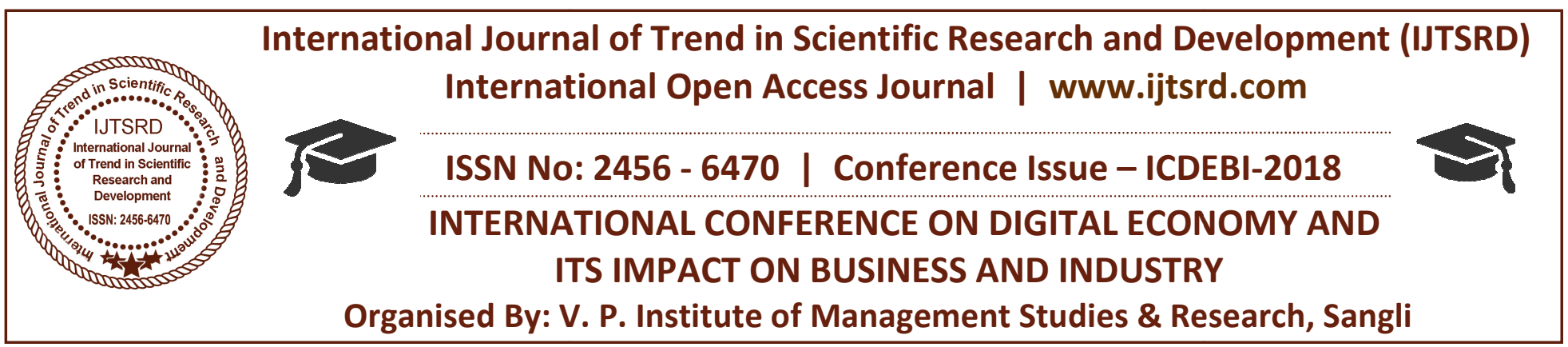

\title{
Library Consortia: A new way of Resource Sharing in Networked Era
}

\author{
Mr. Jadhav S. L ${ }^{1}$, Mr. Yadav R. $D^{2}$ \\ ${ }^{1}$ Librarian College of Education, Barshi, Maharashtra, India \\ ${ }^{2}$ Librarian Smt. C. B. Shaha Mahila Mahavidhyalay, Sangali, Maharashtra, India
}

\section{ABSTRACT}

The advancement of technology on one side and its application in libraries to other side, leads to the changes in libraries from single platform to network based system of libraries such as library consortia. The present paper highlights the concept and meaning of library consortium, why the library consortium is needed, features of library consortium. The attempt has also been made to discuss some models of consortium, and prerequisites for formation of library consortium with issues related to library consortium etc.

\section{INTRODUCTION}

During the last few decades, tremendous information revolution and proliferation have brought about drastic changes to the function and services in all type of libraries. Information exchange or sharing of information takes new mode of cooperation. With the infusion of ICT, the cooperation mode has gone under a transformation from print based environment to digital environment and which results in the formation of new term library consortium. Library consortium is not a new phenomenon, previously it was known as library cooperation or library resource sharing. But due to advancement of technology on one hand and its application in libraries on other hand, the libraries are changing from single platform to network based system of libraries such as library consortia. In library consortia, sharing of library resources is done to have mutual benefits for providing services to its users and to fulfill their demands. Information is considered as a vital resource for communication and for effective use of information, it is necessary that it should be shared. The motto of consortium is choosing, purchasing and implementing the same integrated library system. Primary purpose of establishing a Library Consortium is to share physical resources. However, increasing number of publishers is using the internet as a global way to offer their publications to the global community of users.

\section{Library Consortia: Concept}

A Library Consortium is a group of two or more libraries that have agreed together to cooperate with each other in order to fulfill certain similar needs usually resource sharing. It is not about sharing the resources but also improving access of information.

\section{Definitions of Library Consortia:}

Hirsh on (1999) explained that "Library Consortia is a generic term to indicate any group of libraries that are working together towards a common goal whether to expand cooperation on traditional library services such as collection development or electronic information services".

\section{Reasons for Library Consortium:}

\section{Information explosion:}

Now days, information is exploiting in various forms and it is impossible for any individual library to acquire information in all the form. In that case it has become essential to acquire resources through Library Consortia.

\section{$>$ Diversity of user needs:}

Information requirement of user is ever growing and varies from user to user due to information explosion, new forms of information, presence of 
multi-discipline, specialization of subjects etc. Library consortia help to fulfil their individual requirement.

\section{Professionalism:}

Role of library professionals has been changed from mere conservator to facilitator of knowledge and its due to changes has taken place in all the areas.

\section{Financial constraints:}

Today most of the libraries are faced with economic problems and suffering from financial crises. Library Consortia can solve this problem up to the limit through cooperative efforts.

\section{Technological Revolution:}

The rapid progress of information technology through research and development activities all over the world, now tries to satisfy the information need of human being in diverse manner.

\section{Features of Library Consortia:}

$>$ Library Consortia provides $24 * 7$ availability of information and resources to the users.

$>$ Library Consortia promotes e-Publishing of information variously.

$>$ Library Consortia assists in direct purchasing from publisher which helps to reduce the cost of purchase. It also promotes rational use of funds.

$>$ Library consortia helpful in developing technical capability of staff.

$>$ Library Consortia proves very helpful and supporting in providing back volume of information.

> Through library consortia sharing of information and resource in different formats or languages is possible which avoids barrier of language.

$>$ It provides different subscription level such as cost benefit per subscription.

$>$ It avoids space problem as using Library Consortia one don't need to purchase or acquire every resource in the library.

$>$ Library consortia help in development of ICT environment which make possibility of obtaining best reading for the largest number per institution.

\section{Models of Consortia:}

Below discussed some of the models of consortia are very useful in formation of library consortia:

\section{$>$ Open Consortia:}

This type of consortia is open ended and participating libraries have the freedom to join or leave from consortium at any time. INDEST consortium is an example of open consortia.

\section{$>$ Closed Group Consortia:}

This type of consortia formed by the same type of member and has a common need to cross the resources in specific area. Examples of this type of consortia are CSIR, DAE, IIM etc.

\section{Centrally Funded Model:}

This type of Consortium depends on the central funding agency and parent body shoulders the financial responsibility of running the consortia. For example INDEST, UGC INFONET, CSIR, ICMR etc,

\section{Share Budget Model:}

The formation of such type of consortia is with the appropriate sharing of funds with of participation member and management of fund is individually handled. IIM and FORSA are examples of this model.

\section{Publishers Initiatives:}

In this type of consortia publisher offered a deep discount consortium price to participating libraries. For example SCIENCE DIRECT, EMRALD,

\section{Subject based Consortia:}

These types of Consortia deal with specific subject. FORSA, UGC, DAE are examples of this type of model.

\section{Regional Consortia:}

These types of Consortia covers specific region. Chandigarh Library Consortia is example of such type of Consortium.

\section{E-Journal Consortia:}

INDEST, JIM Consortia, ICAR Consortia are examples of E-JOURNAL Consortia.

\section{Prerequisite for Consortia Formation:}

Formation of consortia needs most important four prerequisites which are discussed below: 
$>$ Hardware:

It must necessarily be a Pentium PC/ Server which would support modular enhancements likes CD Writer, document Scanner, CD Net and other network elements.

\section{Software:}

It composed of different components like operating system, which could be either commonly used Windows or UNIX, LINUX etc and any library software which would enhance handling in house resources in an information centre.

\section{Netware:}

One of the major elements for successful Library Consortia is a good network infrastructure in addition to LAN. The campus internet connectivity with a decent bandwidth has to be provided. This could be made possible only with dedicated telephone line and must also be supplemented by fax facility.

\section{Human Ware:}

Library personnel need to be trained in using latest gadgets with which relevant information is stored, analyzed and disseminated to potential users. Training must also be given to library staff to create databases of library documents.

\section{Library Consortium: Issues}

$>$ Identification of resources is the major issue in library consortium.

$>$ Lack of technological infrastructure.

$>$ Pricing issues.

$>$ Issues related to the access. The problem of access rights, direct access from publishers and through nodal agency by mounting the database on them.

$>$ Licensing and copyright issues.

$>$ Archival issues- at the end of year the publishers should supply access to that issue permanently or supply a copy of that issue in CD or other form.

$>$ Lack of training for users and staff. Library Consortia required special skills in handling EResources.

$>$ Lack of coordination. Library Consortia are lacking for co-ordination of present activities and preparation of new ones.

\section{Conclusion:}

In the age of technology, providing access to information resources is more important than the collection building. Libraries in India are facing major problem of static budget and growing prices of library collection. It is difficult for any single library to monitor all the explosion of knowledge filed and accumulate for the users. In last few years a lot of efforts have been taken to overcome the major problems faced by the libraries and best possible solution to this is sharing of resources through library consortium. There is no doubt that library consortia will be able to share the resources for more effectively and efficiently than individual libraries. A successful consortium is based on the principal that, consortium have clear goals, a coherent membership and a structure that matches its goals and membership.

\section{References:}

1. Md. Ashikuzzaman (2018), Library Consortia: Meaning, Definition, and Growth, Available at http://www.lisbdnet.com/library-consortia-mdg/

2. Parveen, N. (nd). Perception and use of library consortia among scientists in Agricultural Institutes of Uttar Pradesh.

3. Bansode, Sadanand Y (2018). Library Consortia in India: issues and Prospects, Available at: https://www.researchgate.net/profile/Sadanand_B ansode2/publication/265260346_Library_Consorti a_in_India_LIBRARY_CONSORTIA_IN_INDIA _ISSUES_AND_PROSPECTS/links/54d50d190cf 2970e4e642556/Library-Consortia-in-IndiaLIBRARY-CONSORTIA-IN-INDIA-ISSUESAND-PROSPECTS.pdf?origin=publication_detail

4. Singh, Kunwar \& Bhaskar Rao, V. (2018), An Overview of the Library Consortia in India, Available at: https://www. researchgate. Net /profile/Kunwar_Singh19/publication/265434784_ An_Overview_of_the_Library_Consortia_in_Indi a/links/58450c1208aeda696819187c/An Overview-of-the-Library-Consortia-in India. pdf? origin $=$ publication detail 